\title{
Acute Toxoplasmosis During Pregnancy: A Hard Call
}

\author{
Gebelikte Akut Toksoplazmoz: Zor Karar
}

\author{
(1) Tonay İnceboz ${ }^{1}$, (1) Metin Korkmaz², (1) Derya Dirim Erdoğan², (1) Ümit İnceboz ${ }^{3}$ \\ ${ }^{1}$ Dokuz Eylül University Faculty of Medicine, Department of Medical Parasitology, İzmir, Turkey \\ ${ }^{2}$ Ege University Faculty of Medicine, Department of Medical Parasitology, İzmir, Turkey \\ ${ }^{3}$ Irenbe Obstetrics, Gynecology and IVF Center, İzmir, Turkey
}

Cite this article as: İnceboz T, Korkmaz M, Dirim Erdoğan D, İnceboz Ü. Acute Toxoplasmosis During Pregnancy: A Hard

Call. Turkiye Parazitol Derg 2021;45(3):223-226.

\begin{abstract}
Toxoplasma gondii is an obligate intracellular parasite that infects all animals, including humans, and causes toxoplasmosis. If toxoplasmosis occurs during pregnancy, it may affect the foetus owing to transplacental transmission. Such transmission may lead to foetal complications, some of which can be very serious, e.g. hydrocephaly and chorioretinitis; however, not all cases of acute toxoplasmosis during pregnancy result in foetal complications. The decision whether to continue or terminate the pregnancy is a difficult problem for families as well as healthcare professionals, thus making it important. Here we present a case of acute toxoplasmosis at 6 weeks of pregnancy. The patient was directly advised to terminate the pregnancy. However, with detailed laboratory analyses, close follow-up and treatment to prevent transplacental transmission, she successfully completed the pregnancy and eventually delivered a healthy baby. By presenting this case, we aimed to review acute toxoplasmosis during pregnancy.
\end{abstract}

Keywords: Toxoplasma gondii, pregnancy, risk factors, congenital toxoplasmosis, seroprevalence

\section{ÖZ}

Toxoplasma gondii, insanlar dahil tüm hayvanları enfekte edebilen bir zorunlu hücre içi parazittir. Toxoplasma gondii’nin yaptığ1 hastalığa toksoplazmoz denir. Eğer toksoplazmoz gebelikte söz konusu olursa fetus transplasental geçişle etkilenebilir. Her ne kadar bu geçiş, hidrosefali, koryoretinit gibi çok ciddi fetal problemlere yol açsa da, tüm gebelik akut toksoplazmozlarında bu durum mutlaka önemlidir. Çünkü gebeliğe devam etme veya sonlandırma kararı hem aileler için hem de sağlıkçılar için zordur. Burada, akut toksoplasmoz tanısı ile gebeliğin 6. haftasında doğrudan gebelik sonlandırması ile başvuran, gebeliği arzu edilen bir olgu sunuyoruz. Olgu, detaylı laboratuvar testleri, yakın takip ve transplasental geçişi engelleyen tedavi ile gebeliği başarılı bir şekilde sonlandırıp sağlıklı bir bebek sahibi olmuştur. Bu olgu ile, gebelikte akut toksoplazmoz konusunu yeniden gözden geçirmeyi hedefledik.

Anahtar Kelimeler: Toxoplasma gondii, gebelik, risk faktörleri, konjenital toksoplasmoz, seroprevalens

\section{INTRODUCTION}

Toxoplasmosis is a disease in human and most animals caused by Toxoplasma gondii (T. gondii), which is an intracellularly protozoa $(1,2)$. It affects reticuloendothelial system and neural system. In most infected-individuals, course of toxoplasmosis is asymptomatic. Nevertheless, in some individuals, it may cause fever, lymphadenopathy, fatigue, headache, anemia. It may also be a life-threatening problem in immune-suppressed peoples. If the acute infection occurs during pregnancy, transplacental (vertical) transmission may occur and may lead fetal problems such as intracranial calcifications, hydrocephaly and even intrauterine fetal demise. Due to these kind of risks during the pregnancy, serologic testing for toxoplasmosis is being advised or is even mandatory in some countries (3-5).

The acute toxoplasmosis is uncommon during the pregnancy and it is somewhat "tricky"; on one hand 
the treatment of the pregnant is important, on the other hand the investigation should be directed to fetus as to whether the fetal transmission is present and if so, the degree of the fetal damage should be searched. However, sometimes it is not as easy as its theory. The role of the healthcare providers is to explain the whole picture in detail and ask the couple decide the fate (4). Serologic testing, ultrasonographic follow-up -especially for the signs of any fetal involvement- are utmost important.

Here we aimed to present the course of a case with acute toxoplasmosis that was diagnosed in very early pregnancy, and ended up with a healthy baby girl. By doing so, we would like to review the knowledge on toxoplasmosis and pregnancy.

\section{CASE REPORT}

Twenty-four year-old woman, G1P0 was admitted to our clinic with a six-week pregnancy and the diagnosis of toxoplasmosis. She was advised to have a pregnancy termination with the information of high risk of having an "abnormal baby". She was anxious because she had a strong desire of continuation of pregnancy, contradicting with the fear of -mentioned risk of having- "abnormal baby". She had a history of raw-meat consumption. She had no fever but malaise that may be a common feeling during the first months of pregnancy. She had no lymphadenopathy nor hepatosplenomegaly during the physical examination however she had fatigue. Transient increase in the liver function tests namely aspartate aminotransferase (AST) and alanine aminotransferase (ALT) were present. Transvaginal ultrasonographic examination confirmed viable pregnancy of 6 weeks. Table 1 shows serum anti-toxoplasma antibodies (IgM, IgG, IgG-avidity) analyses of the patient performed in three different laboratories (Table 1). It seems an advantage to have the results from three different laboratories in terms of diagnosis and follow-up. When we consider all serological data and elevated liver function test in the present case, it is most likely for her to have the acute toxoplasmosis 1-2 months just before the pregnancy.

The diagnosis, risk of fetal transmission, importance of followups, repeat laboratory analyses, and adherence to prophylactic medication were explained in detail to the couple but she refused to have amniocentesis. They have decided to continue the pregnancy. To decrease the risk of transplacental fetal transmission spiramycine $3 \mathrm{~g} /$ day, orally was started. Follow-up information and was shown in Table 1. Maternal seroconversion was confirmed. Ultrasonographic examinations were all negative for any sign of toxoplasmosis infection. At 39 weeks of pregnancy, she was admitted to the hospital due to rupture of the membranes. Due to cervical dystocia, cesarean section was performed and

\section{Table 1. The patient's serological results for toxoplasmosis during the pregnancy (performed in 3 different labs)}

\begin{tabular}{|c|c|c|}
\hline Weeks of pregnancy & Results & Performed lab \\
\hline $6^{\text {th }}$ week & $\begin{array}{l}\text { IgM: } 11 \\
\text { IgG: } 104\end{array}$ & Private lab \\
\hline $10^{\text {th }}$ week & IgG avidity: $29.72 \%$ & Private lab \\
\hline $12^{\text {th }}$ week & $\begin{array}{l}\text { IgM: } 1.26 \\
\text { IgG: } 1 / 1.024 \text { positive } \\
\text { IgG avidity: } 55 \%\end{array}$ & University hospital lab \\
\hline $18^{\text {th }}$ week & IgG Avidity: 35.86\% & Private lab \\
\hline $23^{\text {th }}$ week & $\begin{array}{l}\text { IgM: } 9.35 \\
\text { IgG: } 59\end{array}$ & Private hospital lab \\
\hline $27^{\text {th }}$ week & $\begin{array}{l}\text { IgM: } 7.81 \\
\text { IgG: } 53.6\end{array}$ & Private hospital lab \\
\hline Postpartum $1^{\text {st }}$ week & $\begin{array}{l}\text { IgM: } 1.11 \\
\text { IgG: } 1 / 512 \\
\text { IgG avidity: } 57 \%\end{array}$ & University hospital lab \\
\hline \multirow{2}{*}{\multicolumn{2}{|c|}{ The reference values of different laboratories }} & $\begin{array}{l}\text { Private lab } \\
\text { IgG: Negative 0-7.2 U/mL, intermediate values: } 7.2-8.8 \mathrm{U} / \mathrm{mL} \text {, Positive: }>8.8 \\
\mathrm{U} / \mathrm{mL} \\
\text { IgM: negative: } 0-10 \\
\text { Avidity. low: }<20 \% \text {, borderline: } 20-30 \% \text {, high: }>30 \%\end{array}$ \\
\hline & & $\begin{array}{l}\text { University hospital lab } \\
\text { IgG (Dilution series, in house ELISA) } \\
\text { IgM (ELFA, bioMérieux diagnostics) negative: }<0.55 \text {; Intermediate }: 0.55- \\
0.65 \text {, positive }>0.65 \\
\text { Avidity. (In house ELISA) low: }<20 \% \text {; Borderline: } 20-30 \% \text {, high: }>30 \%\end{array}$ \\
\hline
\end{tabular}


healthy baby girl (3.190 grams, $50 \mathrm{~cm}$ ) was delivered. The cord blood analysis for toxoplasmosis was negative for IgM but positive for IgG antibodies. Two weeks later IgG was become negative, pointing out the maternal transmission of IgG antibodies. Baby girl is still very healthy and doing well now.

\section{DISCUSSION}

T. gondii is one of the most common parasite that infect around $1 / 3$ of all human in the world (6). The disease caused by T. gondii is called toxoplasmosis and may occur in anyone at any age (79). The incidence of the acute infection during pregnancy is difficult to investigate since the disease is very widespread. However according to one detailed meta-analysis revealed that prevalence of acute toxoplasmosis during pregnancy was around 1.1\% (confidence interval: 0.9-1.2\%) (10). Such an acute infection during pregnancy may affect the baby; it has been estimated that 1 in 1.000-1 in 10,000 babies born with intrauterinely acquired toxoplasmosis (11). In another study, it was estimated that around 190,000 new congenital toxoplasmosis cases occur worldwide annually (12).

Most of the pregnant women with acute toxoplasmosis are asymptomatic (13). In symptomatic cases lymphadenopathy, fatigue, fever, flue-like symptoms may be present. In our case there was no symptom or sign of the acute toxoplasmosis. Although fatigue was present it is not certain whether it was one of a common symptom of pregnancy or due to acute infection with toxoplasma. Transient increase in the liver function tests -namely AST and ALT- were the only abnormal finding in our case. There are some clinical as well as experimental studies pointing out the elevated amino-transferases somewhat a sign of hepatic involvement (14-16). During the follow-up of the present case, hepatic function tests decreased to their normal range. Thus, if some hepatic involvement occurred this was just a transient increase.

Diagnosis of acute toxoplasmosis infection during pregnancy is a difficult task, since such a task put too much stress on both physician, doctors in the lab and as well as the couple involved. In our case we have followed her up with ultrasound examinations and serum analyses. Typically, we have seen the seroconversion. Maternal serology may sometimes be confusing. When rheumatoid factor or antinuclear antibody is positive in the blood, serological tests may be falsely positive $(17,18)$. However serological investigation is mandatory (19). When toxoplasma IgM and IgG are tested, if both are negative, this means no present or past infection. In this situation risk factors such as raw-meat consumption must be avoided. If IgM is negative but IgG is positive, this implies past infection with immunity, thus no risk during pregnancy. If $\operatorname{IgM}$ is positive and $\operatorname{IgG}$ is positive (or negative), this connotes acute infection. IgM antibodies can be detected with in the first 2 weeks of infection, however, IgM titers can remain elevated for a year or more; thus, the presence of IgM antibody is not diagnostic of an acute toxoplasmosis infection. To confirm the diagnosis IgG avidity may help, if this value is high. High-avidity IgG antibodies develop at least 12-16 weeks after the infection. Thus, in a pregnant woman in her first months of gestation, regardless of the IgM antibody test result, a high-avidity IgG test result refers that basically there is no risk for the fetal infection. In our case, at first, both toxoplasma IgM and IgG were both positive. Even if IgG avidity seemed in grayzone, increased IgG avidity results by time also supports early acute infection with toxoplasmosis. In the present case, there are different lab results from different labs. Although just serum IgG and IgM results from the different labs may be confusing for the clinicians, as in our case, serum IgG avidity is "a good guide" to make a decision for such cases. The follow-up serological tests were confirmed this diagnosis as an acute toxoplasmosis during the early stages of pregnancy.

It has been reported that up to two-thirds of cases of congenital toxoplasmosis may not show any abnormality on ultrasound scans (such as calcifications, microcephaly, hydrocephalus, ventricular dilations, hepatosplenomegaly, ascites, and severe intrauterine growth retardation) (20). We have shared this information with the couple. She refused to have invasive diagnostic method (amniocentesis).

Congenital toxoplasmosis may lead to a wide variety of problems from chorioretinitis to fetal death. Classical triad of the congenital infection is chorioretinitis, cranial calcifications and hydrocephalus, however, $90 \%$ of the infants with congenital toxoplasmosis are asymptomatic at birth (21). It should not be forgotten that in the case of being infected with T. gondi, it may cause neuropsychological disorders in the future (22-24). Transplacental transmission of toxoplasma infection is tend to be ironically "fetus friendly". Transmission rate of infection is negligible if the acute toxoplasmosis occurs at or during conception (0-0.6\%) and still low (3.5\%) before 15 weeks of pregnancy, rising steadily, reaching around $80-100 \%$ in the $3^{\text {rd }}$ trimester (25). However fetal damage risk is as the opposite; the damage risk higher if the transmission occurs in early pregnancy, whereas it is very small in late pregnancy. In our case, there were no signs of the fetal involvement and again at birth no signs or symptoms, nor serological clue of a congenital toxoplasmosis infection. The baby girl is still healthy at her 2 years of age now.

In conclusion, toxoplasmosis is very common "neglected" parasitary disease with a risk of fetal transmission if acute infection occurred in pregnancy. However when fetal transmission is not certain, the option of pregnancy termination should not be offered before assessment of the situation in all aspects. The importance of both serological as well as the ultrasonographic follow-up should not be overlooked. There is one other important lesson to remember; serological testing for toxoplasmosis should ideally be checked before the "planned" conception.

\section{* Ethics}

Informed Consent: Informed consent was obtained.

Peer-review: Externally and internally peer-reviewed.

\section{** Authorship Contributions}

Concept: T.I.., M.K., Ü.İ., Design: T.İ., M.K., D.D.E., Ü.İ., Data Collection or Processing: T.I.., M.K., D.D.E., Analysis or Interpretation: T.İ., M.K., D.D.E., Ü.İ., Literature Search: T.İ., M.K., Ü.İ., Writing: T.İ., M.K., Ü.İ.

Conflict of Interest: No conflict of interest was declared by the authors.

Financial Disclosure: The authors declared that this study received no financial support. 


\section{REFERENCES}

1. Montaya JS, Remington JS, Mandell GL, Douglas RG, Bennet JE: Principles and Practice of Infectious Diseases, $5^{\text {th }}$ Ed. Churcill Livingston Inc. New York Chapter 1998. p. 268.

2. Montoya JG, Liesenfeld O. Toxoplasmosis. Lancet 2004; 363: 1965-76.

3. Many A, Koren G. Toxoplasmosis during pregnancy. Can Fam Physician 2006; 52: 29-32.

4. Cook AJ, Gilbert RE, Buffolano W, Zufferey J, Petersen E, Jenum PA, et al. Sources of toxoplasma infection in pregnant women: European multicentre case-control study. European Research Network on Congenital Toxoplasmosis. BMJ 2000; 321: 142-7.

5. Paquet C, Yudin MH; Society of Obstetricians and Gynaecologists of Canada. Toxoplasmosis in pregnancy: prevention, screening, and treatment. J Obstet Gynaecol Can 2013; 35: 78-81.

6. Halonen SK, Weiss LM. Toxoplasmosis. Handb Clin Neurol 2013; 114 : 125-45.

7. Bamba S, Some DA, Chemla C, Geers R, Guigemdé TR, Villena I. Analyse sérologique de la toxoplasmose per gravidique : évaluation desrisques et perspectives du dépistage prénatalau Centre Hospitalier Universitaire de BoboDioulassoau Burkina Faso. Pan Afr Med J 2012; 12: 43.

8. Simpore J, Savadogo A, Ilboudo D, Nadambega MC, Esposito M, Yara J, et al. Toxoplasma gondii, HCV, and HBV seroprevalence and co-infection among HIV-positive and -negative pregnant women in Burkina Faso. J Med Virol 2006; 78: 730-3.

9. Ouermi D, Simpore J, Belem AM, Sanou DS, Karou DS, Ilboudo D, et al. Coinfection of Toxoplasma gondii with HBV in HIV-infected and uninfected pregnant women in Burkina Faso. Pak J Biol Sci 2009; 12: 1188-93.

10. Rostami A, Riahi SM, Contopoulos-Ioannidis DG, Gamble HR, Fakhri Y, Shiadeh MN, et al. Acute Toxoplasma infection in pregnant women worldwide: A systematic review and meta-analysis. PLoS Negl Trop Dis 2019; 13: e0007807.

11. Tenter AM, Heckeroth AR, Weiss LM. Toxoplasma gondii: from animals to humans. Int J Parasitol 2000; 30: 1217-58.

12. Torgerson PR, Mastroiacovo P. The global burden of congenital toxoplasmosis: a systematic review. Bull World Health Organ 2013; 91: 501-8.
13. Van Kessel KA, Eschenbach DA. Toxoplasmosis in pregnancy.In: Gynaecology and Obstetrics. Ed. JJ Sciarra. Lippincott, Williams and Wilkins, Philadelphi:. 3rd Edition, 2004. Chapter 50.

14. Sacks JJ, Delgado DG, Lobel HO, Parker RL. Toxoplasmosis infection associated with eating undercooked venison. Am J Epidemiol 1983; 118: 832-8.

15. Ortego TJ, Robey B, Morrison D, Chan C. Toxoplasmic chorioretinitis and hepatic granulomas. Am J Gastroenterol 1990; 85: 1418-20.

16. Yarim GF, Nisbet C, Oncel T, Cenesiz S, Ciftci G. Serum protein alterations in dogs naturally infected with Toxoplasma gondii. Parasitol Res 2007; 101: 1197-202.

17. Al-Adhroey AH, Mehrass AAO, Al-Shammakh AA, Ali AD, Akabat MYM, Al-Mekhlafi HM. Prevalence and predictors of Toxoplasma gondii infection in pregnant women from Dhamar, Yemen. BMC Infect Dis 2019; 19: 1089.

18. Sirin MC, Agus N, Yilmaz N, Bayram A, Derici YK, Samlioglu P, et al. Seroprevalence of Toxoplasma gondii, Rubella virus and Cytomegalovirus among pregnant women and the importance of avidity assays. Saudi Med J 2017; 38: 727-32.

19. Petersen E, Borobio MV, Guy E, Liesenfeld O, Meroni V, Naessens A, et al. European multicenter study of the LIAISON automated diagnostic system for determination of Toxoplasma gondii-specific immunoglobulin G (IgG) and IgM and the IgG avidity index. J Clin Microbiol 2005; 43: 1570-4.

20. Merz E. Ultrasound in obstetrics and gynecology. Vol. 1: obstetrics. 2nd ed. New York, NY: Thieme; 2004.

21. Remington JS, McLeod R, Desmonts G: Toxoplasmosis. In Remington JS, Klein JO (eds): Infectious Diseases of the Fetus and Newborn Infants, 4th ed. Philadelphia: WB Saunders; 1995. p. 140-267.

22. Tyebji S, Seizova S, Hannan AJ, Tonkin CJ. Toxoplasmosis: A pathway to neuropsychiatric disorders. Neurosci Biobehav Rev 2019; 96: 72-92.

23. Feustel SM, Meissner M, Liesenfeld O. Toxoplasma gondii and the bloodbrain barrier. Virulence 2012; 3: 182-92.

24. Inceboz M, Inceboz T. Toxoplasmosis and Neuropsychological Effects. Turkiye Parazitol Derg 2021; 45: 49-55.

25. Foulon W, Naessens A, Lauwers S, De Meuter F, Amy JJ. Impact of primary prevention on the incidence of toxoplasmosis during pregnancy. Obstet Gynecol 1988; 72: 363-6. 